Bulletin de la Société Royale des Sciences de Liège, Vol. 86, special edition, 2017, p. 651 - 666

\title{
The relationship between capital structure and accounting criteria for evaluating the performance of companies listed on the Tehran Stock Exchange
}

\author{
Hashem Zeidabadi NEZHAD ${ }^{1}$, Hosein Vosoughi NASAB ${ }^{2}$, Mahmoodreza RAKHSHANI ${ }^{3}$ \\ ${ }^{1}$ MA of Accounting, Department of Accounting, College of Humanities, Zahedan Branch, Islamic \\ Azad University, Zahedan, Iran. \\ ${ }^{2}$ Instructor, Department of Accounting, College of Humanities, Zahedan Branch, Islamic Azad \\ University, Zahedan, Iran \\ ${ }^{3}$ Instructor, Department of Accounting, College of Humanities, Zahedan Branch, Islamic Azad \\ University, Zahedan, Iran
}

\begin{abstract}
Capital structure is basically a significant issue in modern financial theory which has drawn the attention of researchers within past few decades. Finance requirement results from two fact. First, value of companies creates demand for financing the purchase of new assets, increase in capacity of plant, employment of new workers, and purchase of raw materials. Second, the finance is determined in terms of financial resources. The present study aims to examine the association between capital structure and accounting and economic standards of performance evaluation of companies enlisted in Tehran Stock Exchange. The independent variable of present study is capital structure (financial leverage) and accounting standards of performance evaluation (i.e. return on assets, the rate of annual stock return, Tobin's Q ratio and the ratio of book to market value) are presumed to be dependent variables. The variable of firm size is regarded as control variable. Data collection method consists of library review and analysis of financial statements. Correlation method and multivariate regression test were used for data analysis. The results of present study suggest that there is a significantly negative association between capital structure and accounting standards of performance evaluation. In addition, the size of company has a significantly negative association with accounting and economic standards of performance evaluation of companies enlisted in Tehran Stock Exchange.
\end{abstract}

Keywords: Capital Structure, Financial Leverage, Annual Return of Stock, Tobin's Q Ratio, Return on Assets.

\section{Introduction}

Finance-related decisions and determination of optimal combination of capital structure on one hand and on other hand, attention to risk of company especially the risk associated with ability to pay debts back are issues that are significant in management decision making (Jola and Islami Bidgoli, 2010). One of the most significant elements of any economic activity is supplying required 
finance which could be generated through shareholder's equity or debt. In this regard, in different companies financial managers guarantee the best combination of financing resources and capital structure. In this regard, decisions made aim to increase value of companies. Capital structure is among those problems regarding which numerous studies and tests have been conducted. At the moment, many theoretical studies and experimental analysis have been conducted (Keshavarz and Mosavi, 2011).

Investment is essential for economic development of any country. In order to offer sufficient finance for investment, some sources of finance should exist. For financing, financial managers should consider different sources, risk and efficiency of the company and their influence on risk and return of stocks of companies enlisted in stock exchange should be attended to. The factors which determine the risk of a company are numerous. One of these factors is capital structure of a company, namely how much shareholders' capital and debt are included in capital structure. Holding debt creates a set of fixed obligations (financial costs) for a company. Therefore, such fixed obligations increase risk of the company because if company cannot pay the debt and its interest it will undergo financial complications (Jola and Islami-Bidgoli, 2010). One of the significant factors affecting return and efficiency of typical shares is capital structure decisions. The use of cheap debt might reduce costs of firm capital and increase financial risk and bankruptcy cost (Stiglitz, 2012).

Considering the significance of capital structure and financial performance of companies, the primary problem of present study is concerned with "influence of capital structure on economic and accounting standards of performance evaluations of companies enlisted in Tehran Stock Exchange".

\subsection{Problem Statement}

Making decisions of capital structure is one of the most challenging and problematic issues that companies face. It is one of the most critical decisions which determine their survival. The review of academic studies and works suggests that the main reason behind failure of companies is either lack/deficiency of investment or their improper/insufficient financing and investment. Most owners of small companies lack strong business skills. Consequently, they lack a proper understanding of conditions and activity of financial markets and suppliers of financial resources. For instance, owners of these companies might select an improper combination of resources (debt against equity), obtain sources that generate high financial obligations for them, or sign certain contracts which impose a lot of liabilities over them. They might even visit financiers dealing with whom is difficult. Therefore, existing weaknesses might result in improper investment which threaten survival of a company. Improper capital structure affects all activities of a company, especially smaller companies. This could result in some problems such as inefficient marketing of products, unproductivity and failure to use proper human resources (Utami, 2012).

On the other hand, the underlying reason behind need for evaluating performance of companies is significance of capital market. Capital market plays a significant role in national economies. The market not only flows stagnant capital through companies but also acts as indicator of economic prosperity of countries. Therefore, attention to this market and basic principles of decision making 
in it is essential. Obviously, investors' engagement in a company is to obtain proper return. If a company creates value successfully, investors and personnel of the company in particular and the society in general will benefit. Performance measurement in decision-making process, considering the significance of capital market, is one of the most significant issues of financial economy. Therefore, financial and economic measures are significant for assessing performance of companies (Azizi and Alame Jafari, 2012),

\subsection{Literature Review}

Utami et al (2012) conducted a study concerning capital structure and organizational life cycle of Indonesia manufacturing companies. They sought to answer the question, "Among Indonesian companies, which company follows hierarchy theory and why?". In the present study, companies are divided into growing companies and mature companies. The results suggested that hierarchy theory describes financial patterns of growing companies better than mature companies. Meanwhile, mature companies tend to solve their financing problems through awarding shareholding rights (public issuance of shares) while growing companies resolve this problem through debt (i.e. bank loans) (Utami, 2012).

In a paper titled, "Hierarchy theory and organizational life cycle", Bolan and Yan (2009) reviewed main computations of hierarchy theory of finance in companies positioned in two different cycles of organizational life cycle: companies at growing period of organizational life and companies in their maturity. The results of present study suggest that after imposing sufficient controls on debt taking limitation and among different steps of organizational life cycle, where debt taking capacity and foreign financing requirement are more homogenous, companies which select costs improperly are more likely to follow hierarchy theory (Bolan, 2009).

Sadjadi and Jafari conducted a study on capital structure and factors affecting it through reviewing 70 companies in a period of time leading to late 2011. Through library reviews, theoretical principles of present study were highlighted. In addition, review of accounting documents and data checklists of companies contributed to collection of data for further analysis and making decisions in regard to research hypotheses. Parametric and non-parametric statistical techniques were used for data analysis. The results suggested that capital structure of companies is significantly associated with size of company, age of managers, level of education, preferences and ages of owners. However, there was no association between capital structure of companies and their age or familiarity of managers with financial concepts.

Haezi et al (2015) conducted a study concerning theoretical principles of financing, capital expenses and capital structure. The paper reviews financing methods, capital expenses and associated theories. In addition, the significance of association between capital expense, capital structure and value of the whole company from managers' viewpoint is discussed since capital structure could affect total value of the company. One could determine the desirable structure of the company based on above presumptions, investor's perceptions and their reaction to variation of financial risk. However, one cannot completely revolve conflict of interests of holders of company's securities and typical share (Azizi, 2012). 


\subsection{Methodology}

The present study is methodologically regarded as a descriptive survey. The relevant retrospective data was collected from previous documents and evidence. Considering location of present study, the statistical population of present study includes all companies enlisted in Tehran Stock Exchange during 2011-2015. The statistical sample is selected based on the following conditions:

1- Required financial information such as financial statements and associated notes for relevant companies is available for intended period of time.

2- The companies are enlisted in Tehran Stock Exchange up to 2011.

3- Financial year of the companies ends in March $19^{\text {th }}$ of each year.

4- The companies that have not changed their financial period during 2011-2015.

5- Complete information and descriptive notes associated with financial statements of companies are available.

In order to develop theoretical principles of present study, library review was done and information related to theoretical principles of present study were collected from English and Persian books and papers. Field-based and recorded-in-library data collection was accompanied with visiting Tehran Stock Exchange and electronic publications. To do this, relevant data was collected in Excel table and research variables were determined through EVIEWS Software.

\subsection{Research Hypotheses}

H.1-There is a significant association between capital structure and Tobin's Q ratio.

H.2-There is a significant association between capital structure and return of assets.

H. 3- There is a significant association between capital structure and annual return of shares.

H. 4- There is a significant association between capital structure and ratio of book to market value.

\subsection{Research Variables}

\subsubsection{Independent Variable}

Capital Structure: In present study, the variable of financial leverage is used for measuring capital structure (Hasas Yeganeh, 2010).

Financial Leverage of Company: In regard to conceptual definition, one should note that the ratios determine the association of financial resources used in a business unit in terms of shareholders' obligations and rights and reviews their way of combination.

In terms of operational definition, financial leverage of companies is determined by division of book value of long-term assets by total assets (Sinai and Nisi, 2003). 


\subsubsection{Control Variable}

Size of Company: There are numerous measures for determining the variable "size of company" such as total value of assets, level of sales and total number of employees.

In an operational definition, size of company was defined by Lee (2008) as Nehprii logarithm of total assets.

\subsubsection{Dependent Variables}

Conceptual Definition: From a conceptual approach, Tobin's Q ratio is a statistic which could represent the value of a company for investors. Through the ratio, shareholders could perceive to what extent management is involved increase of their wealth (Zeraatgari, 2007).

From an operational definition, Tobin's Q ratio is defined through the following definition (Leewillen and Badernet, 1997).

$$
\text { Tobin's } \mathrm{Q}=\frac{\text { VOCSILOY }+ \text { EMVOPSILOY }+ \text { BVLTLILOY }+ \text { BVCLILOY }}{B V T A I L O Y}
$$

In above expression, we have:

VOCSILOY: Value of Typical Share at End of Year

EMVOPSILOY: Estimation of Preferred Stock Exchange Value at End of Year

BVCLILOY: Book Value of Current Obligations at End of Year

BVTAILOY: Book Value of All Assets at End of Year

BVLTLILOY: Book Value of Long-term Assets at End of Year

Considering the fact there is no preferred share, value of EMVOPSILO is considered to be equal with zero.

\subsection{Return on Assets}

Conceptual Definition: Return on assets refers to the association between profitability of a company and its total assets (Lee, 2008).

Operational Definition: In this viewpoint, return on assets is determined by division of total profit to total assets of the company.

\subsection{Annual Return on Shares}


Conceptual Definition: Annual return on shares refers to total profit assigned to a shareholder in a definite period of time.

Operational Definition: Annual return on shares is defined as price variation of first and last period of shareholding plus other benefits of buying shares such as benefits of preemptive rights, dividend and cash dividend divided by the price of shares during the first period (Resaian and Asghari, 2007).

\subsection{Price Change}

Variation in price of a share during a period of time acts as main factors affecting return which might be termed as either "profit" or "loss" of capital.

\subsection{Cash Dividend per Share}

Cash dividend per share is the amount of money paid to shareholders after tax deduction. It is called "share dividend" too.

Benefits of Preemptive Rights to Buy Shares:

Shareholders of public companies are prioritized over potential shareholders in purchase of new share that a company issues to increase its capital. Within a deadline, previous shareholders could enjoy the right and the right has trading value.

\subsection{Market to Book Ratio}

Conceptual Definition: Market to book ratio or product of share price divided by book value. It is deemed as a new measure based on which a share might be trade to multiple times of its book value. Operational Definition: $\mathrm{P} / \mathrm{B}$ ratio is product of division of market value of the company divided by its book value.

\section{Findings}

Descriptive Analysis of Research Variables

Table 1: Descriptive Analysis of Research Variables.

\begin{tabular}{|c|c|c|c|c|c|c|c|c|}
\hline Variable & No. & Minimum & Maximum & Mean & SD & Variance & Skewness & Kurtosis \\
\hline CS & 455 & .198 & 1.018 & .768 & .013 & .120 & .312 & -.121 \\
\hline Q & 455 & 5.96 & 19.026 & 7.776 & .159 & .115 & .943 & .389 \\
\hline ROA & 455 & 1.132 & 3.84 & 2.365 & .142 & .025 & -.299 & .213 \\
\hline SRE & 455 & .475 & 1.663 & .965 & .119 & 0.217 & .369 & .163 \\
\hline P/E & 455 & .80 & 9.36 & 2.935 & .453 & .286 & .291 & .115 \\
\hline SIZE & 455 & .13 & 4.99 & 2.021 & .156 & .327 & .306 & .209 \\
\hline
\end{tabular}

Note: Number of observation in descriptive statistic of companies is 455 (91 companies per 5 year). 
Bulletin de la Société Royale des Sciences de Liège, Vol. 86, special edition, 2017, p. 651 - 666

Based on descriptive statistic, distribution of variables for different companies is low. The highest standard deviation is related to Tobin's $Q$ ratio and lowest standard deviation is associated with capital structure.

A review of skewness and kurtosis of variables and comparison of them with normal distribution suggest that all research variables have normal distribution because when absolute values of skewness and kurtosis is high one may conclude that it has high difference from normal distribution.

High skewness suggests density of numbers towards negative or positive values. In addition, kurtosis is associated with height of the diagram of variables distribution.

\subsection{Normality of Variables}

In order to review normality of variables, Kolmogorov-Smirnov test was used in present study.

Table 2: Normality of Variables

\begin{tabular}{|c|c|c|}
\hline Variables & Kolmogorov-Smirnov $(\mathrm{Z})$ & Level of Significance \\
\hline CS & 2.031 & .238 \\
\hline $\mathrm{Q}$ & 1.741 & .642 \\
\hline ROA & 1.777 & .582 \\
\hline SRE & 1.247 & .447 \\
\hline P/E & 1.968 & .311 \\
\hline SIZE & 1.091 & .945 \\
\hline
\end{tabular}

As one could note, significance levels of all variables is more than 0.05 . Therefore, research variables have normal distribution.

\subsection{Correlation Test}

Table 3: Pearson Correlation Test of Research Variables

\begin{tabular}{|c|c|c|c|c|c|c|c|c|}
\hline CS & 1 & $-.853^{*}$ & $.294^{*} *_{-}$ & $-.432^{* *}$ & $-.520^{* *}$ & $-.452^{*}$ & $-.064^{*}$ & -.004 \\
\hline EVA & $-.853^{*}$ & 1 & .385 & .407 & .196 & .308 & $.093^{*}$ & $.050^{*}$ \\
\hline MVA & $-.294^{* *}$ & .385 & 1 & .180 & .083 & .157 & .096 & $.010^{*}$ \\
\hline Q & $-.432^{* *}$ & .407 & .180 & 1 & .068 & .371 & .081 & $.030^{*}$ \\
\hline ROA & $-.520^{* *}$ & .196 & .083 & .068 & 1 & .311 & .027 & $.038^{*}$ \\
\hline SRE & $-.452^{*}$ & .308 & .157 & .371 & .311 & 1 & .087 & $.039^{*}$ \\
\hline P/E & $-.064^{*}$ & $.093^{*}$ & .096 & .027 & .027 & .087 & 1 & $.374^{* *}$ \\
\hline SIZE & -.113 & $.050^{*}$ & $.010^{*}$ & .038 & $.038^{*}$ & $.039^{*}$ & $.137 * *$ & 1 \\
\hline
\end{tabular}

**: Significance at \%1 Error

*. Significance and \%5 Error 
Bulletin de la Société Royale des Sciences de Liège, Vol. 86, special edition, 2017, p. 651 - 666

\subsection{Regression Significance Test}

As F-statistic in all regression tables suggests, regression model of all tests of hypotheses is significant because their levels of significance are less than 0.05 .

\subsection{Co-linearity Test}

Table 4: Colinearity Test

\begin{tabular}{|c|c|c|}
\hline Variables & Eigenvalue & Status of Index \\
\hline 1 & 0.948 & 3.832 \\
\hline 2 & 0.983 & 4.217 \\
\hline
\end{tabular}

Observably, when eigenvalues are close to zero internal consistency of predictions are high and small variations of values of data leads to large variations in estimation of regression coefficient. The eigenvalues suggest the probability of internal consistency between variables.

When status indicator is higher than 15, it signifies probability of co-linearity between independent variables. If value of this indicator exceeds 15 , it creates a serious problem in using regression in existing condition (Hassas Yegane et al, 2010). On the other hand, all status indicators which are below 15 suggest the lack of co-linearity between independent variables.

\subsection{Auto-correlation Test}

The use of Durbin-Watson statistic for test of hypotheses suggests lack of auto-correlation between research variables. As regression test tables suggest, the statistic ranges from 1.5 to 2.5. Therefore, there is no autocorrelation problem between research variables.

\subsection{Test of Hypotheses and Results}

Table 5: F Limer Test

\begin{tabular}{|c|c|c|c|c|c|}
\hline Zero Hypothesis & $\begin{array}{c}\text { Research } \\
\text { Models }\end{array}$ & F-statistic & $\begin{array}{c}\text { Degree of } \\
\text { Freedom }\end{array}$ & P-value & Test Result \\
\hline $\begin{array}{c}\text { Intercept of all } \\
\text { sections are } \\
\text { identical }\end{array}$ & Model 1 & 2.6453 & 2 & 0.000 & H0 is denied. \\
\cline { 2 - 6 } & Model 2 & 1.1325 & 2 & 0.000 & H0 is denied. \\
\cline { 2 - 6 } & Model 3 & 1.0231 & 2 & 0.000 & H0 is denied. \\
\hline
\end{tabular}

In F test, zero hypothesis is regarding the use of integrated data against alternative hypothesis (i.e. use of panel data). Considering the significance level of above table, results of this test suggest that analyzed sections are heterogeneous and use of panel data is more suitable. After selection of panel data, Hausman test was conducted through F Limer test. In the present study, if zero hypothesis (H0) is supported the random effects model is used. If HO is denied, fixed effects model will be used. 
Bulletin de la Société Royale des Sciences de Liège, Vol. 86, special edition, 2017, p. 651 - 666

Table 6: Results of Hausman Test (Selection between Fixed and Random Effects)

\begin{tabular}{|c|c|c|c|c|c|}
\hline Zero Hypothesis & $\begin{array}{c}\text { Research } \\
\text { Models }\end{array}$ & $\begin{array}{c}\text { Chi-square } \\
\text { Statistic }\end{array}$ & $\begin{array}{c}\text { Degree of } \\
\text { Freedom }\end{array}$ & P-value & Test Result \\
\hline $\begin{array}{c}\text { There is no } \\
\text { difference in } \\
\text { systematic } \\
\text { coefficients. }\end{array}$ & Model 1 & 5.4503 & 2 & 0.000 & H0 is denied. \\
\cline { 2 - 7 } & Model 2 & 4.4528 & 2 & 0.000 & H0 is denied. \\
\cline { 2 - 7 } & Model 3 & 4.3452 & 2 & 0.000 & H0 is denied. \\
\hline
\end{tabular}

As results suggest, value of this statistic is significant for each model and significance level of above table ( $\mathrm{p}$-value<0.05) denied zero hypothesis (H0) at $95 \%$ confidence level for all models. This suggests that fixed effects method is recommended.

\subsection{Test of First Hypothesis}

Table 7: Results of Multivariate Regression between Tobin's Q Ratio and Capital Structure

\begin{tabular}{|l|c|l|c|c|c|}
\hline Type of Variable & Sign & \multicolumn{1}{|c|}{$\begin{array}{c}\text { Name of } \\
\text { Variable }\end{array}$} & Coefficient & T-statistic & $\begin{array}{c}\text { Level of } \\
\text { Significance }\end{array}$ \\
\hline $\begin{array}{l}\text { Dependent } \\
\text { Variable }\end{array}$ & $\mathrm{Y}$ & Tobin's Q Ratio & --- & --- & --- \\
\hline Fixed Value & $a$ & Alpha & 1.445 & 1.365 & 0.000 \\
\hline $\begin{array}{l}\text { Independent } \\
\text { Variable }\end{array}$ & XI & Capital Structure & $-0.229^{*}$ & -1.118 & 0.000 \\
\hline Control Variable & Size of Company & $0.387^{*}$ & 1.254 & 0.000 \\
\cline { 3 - 6 } & Durbin-Watson & 1.894 & ---- & --- \\
\cline { 3 - 6 } & F-statistic & 6.987 & ---- & 0.001 \\
\hline R & $\begin{array}{l}\text { Correlation } \\
\text { Coefficient }\end{array}$ & 0.702 & --- & -- \\
\hline R-square & $\begin{array}{l}\text { Coefficient of } \\
\text { Determination }\end{array}$ & 0.492 & --- & -- \\
\hline $\begin{array}{l}\text { Adjusted } \\
\text { square }\end{array}$ & $\begin{array}{l}\text { Adjusted } \\
\text { Coefficient } \\
\text { Determination }\end{array}$ & 0.491 & --- & \\
\hline
\end{tabular}

Note: * Level of significance is equal with 0.05 . 
Bulletin de la Société Royale des Sciences de Liège, Vol. 86, special edition, 2017, p. 651 - 666

As above table suggests, capital structure and size of company ( $\mathrm{p}$-value $<5 \%$ ) are significantly associated with Tobin's Q ratio. Coefficients of variables suggest that association of company size with Tobin's Q ratio is higher than its association with capital structure.

The variable of capital structure has a significantly negative association with Tobin's Q ratio while size of company has a significantly positive association with Tobin's $\mathrm{Q}$ ratio.

Based on value of F-statistic, fitted regression model is significant. Concerning coefficient of determination, the variables could explain 49.2 percent of variation of Tobin's $Q$ ratio. In addition, because Durbin-Watson statistic ranged from 1.5 to 2.5 one could conclude that there is no autocorrelation between variables.

\subsection{Test of Second Hypothesis}

Table 8: Multivariate Regression of Return on Assets and Capital Structure

\begin{tabular}{|l|c|l|c|c|c|}
\hline Type of Variable & Sign & \multicolumn{1}{|c|}{$\begin{array}{c}\text { Name of } \\
\text { Variable }\end{array}$} & Coefficient & T-statistic & $\begin{array}{c}\text { Level of } \\
\text { Significance }\end{array}$ \\
\hline $\begin{array}{l}\text { Dependent } \\
\text { Variable }\end{array}$ & $\mathrm{Y}$ & Return on Assets & --- & --- & --- \\
\hline Fixed Value & $A$ & Alpha & 1.545 & 1.405 & 0.050 \\
\hline $\begin{array}{l}\text { Independent } \\
\text { Variable }\end{array}$ & $\mathrm{XI}$ & Capital Structure & $-0.447^{*}$ & -1.950 & 0.002 \\
\hline Control Variable & & Size of Company & $0.745^{*}$ & 1.840 & 0.003 \\
\cline { 2 - 6 } & Durbin-Watson & 1.921 & ---- & --- \\
\cline { 2 - 6 } & F-statistic & 6.950 & ---- & 0.001 \\
\hline $\mathrm{R}$ & $\begin{array}{l}\text { Correlation } \\
\text { Coefficient }\end{array}$ & 0.645 & --- & --- \\
\hline R-square & $\begin{array}{l}\text { Coefficient of } \\
\text { Determination }\end{array}$ & 0.416 & --- & --- \\
\hline $\begin{array}{l}\text { Adjusted } \\
\text { square }\end{array}$ & $\begin{array}{l}\text { Adjusted } \\
\text { Coefficient of } \\
\text { Determination }\end{array}$ & $0 / 415$ & --- & - \\
\hline
\end{tabular}

Note: * suggests that level of significance is equal with 0.05 .

As above table suggests, capital structure and size of company ( $\mathrm{p}$-value $<5 \%$ ) have significant associations with return on assets. The coefficients of variables suggest that size of company has higher correlation with return on assets than capital structure.

The variable of capital structure has a significantly negative association with return on assets. In contrast, size of company has a significantly positive association with return on assets.

Considering the value of F-statistic, fitted regression model is significant. Considering coefficient of determination, the variables could explain 41.6 percent of variation of return on assets. Meanwhile, because Durbin-Watson statistic ranges from 1.5 to 2.5 one may conclude that there is no auto-correlation between variables. 
Bulletin de la Société Royale des Sciences de Liège, Vol. 86, special edition, 2017, p. 651 - 666

\subsection{Test of Third Hypothesis}

Table 9: Multivariate Regression of Annual Dividend and Capital Structure

\begin{tabular}{|l|c|l|c|c|c|}
\hline Type of Variable & Sign & \multicolumn{1}{|c|}{$\begin{array}{c}\text { Name of } \\
\text { Variable }\end{array}$} & Coefficient & T-statistic & $\begin{array}{c}\text { Level of } \\
\text { Significance }\end{array}$ \\
\hline $\begin{array}{l}\text { Dependent } \\
\text { Variable }\end{array}$ & $\mathrm{Y}$ & Annual Dividend & --- & --- & --- \\
\hline Fixed Value & $A$ & Alpha & 1.545 & 1.405 & 0.050 \\
\hline $\begin{array}{l}\text { Independent } \\
\text { Variable }\end{array}$ & $\mathrm{XI}$ & Capital Structure & $-0.447^{*}$ & -1.950 & 0.003 \\
\hline Control Variable & & Size of Company & $0.745^{*}$ & 1.840 & 0.003 \\
\cline { 3 - 6 } & Durbin-Watson & 1.921 & ---- & --- \\
\cline { 3 - 6 } & F-statistic & 6.950 & ---- & 0.001 \\
\hline R & $\begin{array}{l}\text { Correlation } \\
\text { Coefficient }\end{array}$ & 0.645 & --- & --- \\
\hline R-square & $\begin{array}{l}\text { Coefficient of } \\
\text { Determination }\end{array}$ & 0.416 & --- & -- \\
\hline $\begin{array}{l}\text { Adjusted } \\
\text { square }\end{array}$ & $\begin{array}{l}\text { Adjusted } \\
\text { Coefficient of } \\
\text { Determination }\end{array}$ & $0 / 415$ & --- & \\
\hline
\end{tabular}

Note: * suggests that level of significance is equal with 0.05 .

As above table suggests, capital structure and size of company ( $\mathrm{p}$-value $<5 \%$ ) have significant associations with annual dividend. The coefficients of variables suggest that size of company has higher correlation with annual dividend than capital structure.

The variable of capital structure has a significantly negative association with annual dividend. In contrast, size of company has a significantly positive association with annual dividend.

Considering the value of F-statistic, fitted regression model is significant. Considering coefficient of determination, the variables could explain 36 percent of variation of annual dividend. Meanwhile, because Durbin-Watson statistic ranges from 1.5 to 2.5 one may conclude that there is no auto-correlation between variables. 
Bulletin de la Société Royale des Sciences de Liège, Vol. 86, special edition, 2017, p. 651 - 666

\subsection{Test of Fourth Hypothesis}

Table 10: Multivariate Regression of Book to Market Ratio and Capital Structure

\begin{tabular}{|l|c|l|c|c|c|}
\hline Type of Variable & Sign & \multicolumn{1}{|c|}{$\begin{array}{l}\text { Name of } \\
\text { Variable }\end{array}$} & Coefficient & T-statistic & $\begin{array}{c}\text { Level of } \\
\text { Significance }\end{array}$ \\
\hline $\begin{array}{l}\text { Dependent } \\
\text { Variable }\end{array}$ & $\mathrm{Y}$ & $\begin{array}{l}\text { Book to Market } \\
\text { Ratio }\end{array}$ & --- & --- & --- \\
\hline Fixed Value & $a$ & Alpha & 1.589 & 1.113 & 0.000 \\
\hline $\begin{array}{l}\text { Independent } \\
\text { Variable }\end{array}$ & XI & Capital Structure & $-0.331^{*}$ & -1.447 & 0.002 \\
\hline Control Variable & Size of Company & $0.398^{*}$ & 1.229 & 0.000 \\
\cline { 3 - 6 } & Durbin-Watson & 1.796 & ---- & --- \\
\cline { 2 - 6 } & F-statistic & 4.546 & ---- & 0.000 \\
\hline R & $\begin{array}{l}\text { Correlation } \\
\text { Coefficient }\end{array}$ & 0.581 & --- & --- \\
\hline R-square & $\begin{array}{l}\text { Coefficient of } \\
\text { Determination }\end{array}$ & 0.337 & --- & -- \\
\hline $\begin{array}{l}\text { Adjusted } \\
\text { square }\end{array}$ & $\begin{array}{l}\text { Adjusted } \\
\text { Coefficient } \\
\text { Determination }\end{array}$ & 0.337 & -- & - \\
\hline
\end{tabular}

Note: * suggests that level of significance is equal with 0.05 .

As above table suggests, capital structure and size of company (p-value $<5 \%)$ have significant associations with book to market ratio. The coefficients of variables suggest that size of company has higher correlation with book to market ratio than capital structure.

The variable of capital structure has a significantly negative association with book to market ratio. In contrast, size of company has a significantly positive association with book to market ratio.

Considering the value of F-statistic, fitted regression model is significant. Considering coefficient of determination, the variables could explain 33.7 percent of variation of book to market ratio. Meanwhile, because Durbin-Watson statistic ranges from 1.5 to 2.5 one may conclude that there is no auto-correlation between variables.

\section{Conclusion and Discussion}

Findings of present study are as described in the following: 
During study period, capital structure (financial leverage) has a significantly positive association with Tobin's Q ratio of companies enlisted in Tehran Stock Exchange from 2011 to 2015. In other words, higher financial leverage of a company is correlated with its lower Tobin's Q ratio.

During study period, capital structure (financial leverage) has a significantly positive association with return on assets of companies enlisted in Tehran Stock Exchange from 2011 to 2015. In other words, higher financial leverage of a company is correlated with its lower return on assets.

During study period, capital structure (financial leverage) has a significantly positive association with annual dividend of companies enlisted in Tehran Stock Exchange from 2011 to 2015. In other words, higher financial leverage of a company is correlated with its lower annual dividend.

During study period, capital structure (financial leverage) has a significantly positive association with book to market value of companies enlisted in Tehran Stock Exchange from 2011 to 2015. In other words, higher financial leverage of a company is correlated with its book to market value.

The results of present study matches those of Zhing Chan et al (2012), Chen et al (2012), and Tandelo and Wanstreilen (2012).

\section{Suggestions}

Based on existing evidence for present study and results of testing the hypotheses, the following suggestions could be made for Tehran Stock Exchange, management of companies, shareholders, creditors, banks and credit institutes, students and researchers.

Based on results of testing first to third hypotheses, because financial leverage (capital structure) has a significantly negative association with accounting and economic standards of performance evaluation, it is suggested that shareholders and people intending to enter capital market should pay attention to the fact that companies with lower financial leverage will show higher performance.

Managers of companies who intend to enhance their financial performance should reduce their financial leverage and reduce debts of the company.

Securities and Exchange Organization is recommended to develop control and monitoring mechanisms for analysis of companies' financial leverage because as financial leverage of companies increases their risk of bankruptcy will enhance.

Because size of the company has a significantly positive association with accounting and economic standards of performance evaluation, it is suggested that shareholders and individuals intending to enter capital market should pay attention to this fact and invest on large companies. Because large companies have experienced experts and possess sufficient financial resources for participating investment opportunities, they are regarded as good candidates.

\subsection{Suggestions for Further Studies}


1- Reviewing effect of macroeconomic variables, inflation, oil price and exchange rate on association between capital structure and accounting-economic variables of performance evaluation.

2- Studying influence of type of industry on association between capital structure and accountingeconomic variables of performance evaluation.

3- Study of association of capital market with systematic and non-systematic risk

4- Study of association of data asymmetry and accounting quality with accounting-economic variables of performance evaluation.

\section{References}

[1] Aharony J., H Falk \& N Yehuda. (2006). Corporate life cycle and the value relevance of cash flow versus accrual financial information. School of Economics and Management Bolzano, 34 .

[2] Ahmadpur, A \& Salimi, A. (2010). The effect of industry and size on capital structure on structure of companies enlisted in Tehran Stock Exchange. Journal of Social Sciences and Humanities, Shiraz University, 55.

[3] Antoniou, A., Guney, Y. \& Paudyal, K. (2008). The determinants of capital structure: capital market oriented versus bank-oriented institutions, Journal of Financial and Quantitative Analysis, 43(1), 5992.

[4] Azizi, M. A \& Alame Haeri, F. (2014). Theoretical principles of financing method, capital cost an capital structure, Journal of Accounting and Financial Management, 107-129.

[5] Beasli, R.M \& Bringham, C.C. (1999). Evidence on the existence and determinants of inter-industry differences in leverage. Financial Management, 11:10-12.

[6] Bradley, M., Jarrell, G \& Kim, E.H. (2006). On the existence of an optimal capital structure: Theory and evidence. Journal of Finance, 39:857-878.

[7] Ghlibaf Asl. H \& Izadi, S. (2010). Experimental study of static trade-off theory in Tehran Stock Exchange. Journal of Knowledge and Development, 26.

[8] Izadi Nia, N \& Dastjerdi, M. (2007). Effect of capital structure on return on investment, 1: 3.

[9] Jaine, M.A \& Khaine, A. (2007). Finance in family business. Family Business Review, 9(4):387-401.

[10] Jola, G \& Islami Bidgoli, J. (2011). The study of association between capital structure and systematic risk of companies enlisted in Tehran Stock Exchange, Quarterly of Tehran Stock Exchange, 8: 91: 113.

[11] Keshavarz, S \& Mosavi, H. (2014). The study of association between factors affecting capital structure and levels of systematic companies enlisted in Tehran Stock Exchange, Journal of Financial Studies, Tehran University, 16.

[12] Mishckin, M. Z (2011). Trade-Off and Pecking Order Theories of Debt. Handbook of Corporate Finance, 1-82.

[13] Nikbakht, M, R \& Moghimi, A, A. (2014). The study of association between economic value-added and capital structure. Hesabras Magazine, 56. 
Bulletin de la Société Royale des Sciences de Liège, Vol. 86, special edition, 2017, p. 651 - 666

[14] Nikomaram, H., Rahnama Roodpashti, F \& Heibati, F. (2010). Principles of Financial Management, Termeh Publication, 2.

[15] Rai, R. (2010). Financial management, Age Press, 2.

[16] Resaian, A \& Asghari, J. (2007). Study of association between accounting standards of performance evaluation and economic value-added in Tehran Stock Exchange. Mofid Economic Letter. 13: 60, 61: 88 .

[17] Sinai, H., Selgi, M \& Mohammadi, K. (2014). Effect of growth opportunities on association of value of company with capital structure, dividend and ownership structure. Journal of Accounting-Financial Studies, University of Isfahan, 10, 87-102.

[18] Siti Rahmi Utami, E. L. (2012). The Relationship between capital structure and life cycle of firms in the manufacturing sector of Indonesia. International Research Journal of Finance and Economics, 1-23.

[19] Sultani, K,. Saedi, A \& Akhlagi, H. (2014). The study of influence of specific characteristics of a company and strategic tools of company on capital structure based on Tobit model", Journal of Accounting-Financial Studies of University of Tehran. 4: 112-135.

[20] Tehrani, R. (2010). Financial management. Negahe-Danesh Press.

[21] Vakili Fard, H. R. (2014). Decision making on financial issues. Foj Publications, 2. 